\title{
Does release of antimicrobial agents from impregnated external ventricular drainage catheters affect the diagnosis of ventriculitis?
}

\author{
Roger Bayston, PhD, FRCPath, ${ }^{1}$ Waheed Ashraf, MSc, ${ }^{1}$ and Catherine Ortori, $\mathrm{PhD}^{2}$ \\ 1Biomaterials-Related Infection Group, School of Medicine, and ${ }^{2}$ School of Pharmacy, University of Nottingham, United Kingdom
}

OBJECTIVE Recently concern has arisen over the effect of released antimicrobial agents from antibiotic-impregnated external ventricular drainage (EVD) catheters on the reliability of CSF culture for diagnosis of ventriculitis. The authors designed a laboratory study to investigate this possibility, and to determine whether there was also a risk of loss of bacterial viability when CSF samples were delayed in transport to the laboratory.

METHODS Three types of commercially available antibiotic-impregnated EVD catheters were perfused with a suspension of bacteria (Staphylococcus epidermidis) over 21 days. Samples were analyzed for bacterial viability and for concentrations of antibiotics released from the catheters. The authors also investigated the effect on bacterial viability in samples stored at $18^{\circ} \mathrm{C}$ and $4^{\circ} \mathrm{C}$ to simulate delay in CSF samples reaching the laboratory for analysis.

RESULTS Bacterial viability was significantly reduced in all 3 catheter types when sampled on Day 1 , but this effect was not observed in later samples. The results were reflected in stored samples, with significant loss of viability in Day 1 samples but with little further loss of viable bacteria in samples obtained after this time point. All samples stored for 18 hours showed significant loss of viable bacteria.

CONCLUSIONS While there were differences between the catheters, only samples taken on Day 1 showed a significant reduction in the numbers of viable bacteria after passing through the catheters. This reduction coincided with higher concentrations of antimicrobial agents in the first few hours after perfusion began. Similarly, bacterial viability declined significantly after storage of Day 1 samples, but only slightly in samples obtained thereafter. The results indicate that drugs released from these antimicrobial catheters are unlikely to affect the diagnosis of ventriculitis, as sampling for this purpose is not usually conducted in the first 24 hours of EVD.

http://thejns.org/doi/abs/10.3171/2014.12.JNS141900

KEY WORDS external ventricular drainage; infection; antimicrobial catheter; ventriculitis; hydrocephalus

$\mathrm{E}$ XTERNAL ventricular drainage (EVD) is used to control raised CSF pressure after head injury, intracranial hemorrhage, or tumor, or as part of the management of hydrocephalus shunt infection. The ventricular catheter in EVD may be in place for a few days or up to 2-3 weeks, until no longer needed or until malfunction or infection occurs. As the system is not totally internalized, and as CSF is often drawn from it for analysis and pressure monitoring, the risk of infection is high, with rates of up to $20 \%$ having been reported..$^{1,3,11}$ EVD ventriculi- tis is associated with microbial colonization and biofilm formation in the catheter. ${ }^{19}$ The most common causes of EVD ventriculitis are staphylococci of skin origin. Ventriculitis has serious consequences for the patient, leading to poor outcome of the original illness and reduced mental and physical capacity, with implications for education and employment. It can also lead to scarring and loculation of the ventricular system and difficulty in further pressure management. ${ }^{17}$ Due to the initial reason for EVD, patients often already have impaired consciousness

ABBREVIATIONS EVD = external ventricular drainage; HPLC = high performance liquid chromatography; LC-MS = liquid chromatography-mass spectrometry; MIC = minimum inhibitory concentration.

SUBMITTED August 19, 2014. ACCEPTED December 4, 2014.

INCLUDE WHEN CITING Published online June 12, 2015; DOI: 10.3171/2014.12.JNS141900.

DISCLOSURE The authors received financial support for this study in the form of a grant (No. 7397) from the Clinical Research Committee of Codman and Shurtleff Inc. The company had no role in the planning, design, or execution of the project, or any influence on data analysis or the content of the publication. Prof. Bayston is the named inventor of Bactiseal catheters but does not receive royalties or any other financial benefit. 
and other neurological symptoms that make diagnosis of ventriculitis difficult. This is made even more problematic as laboratory parameters such as CSF inflammatory indicators (white blood cell count, lactate levels, etc.) are often already abnormal, and blood in the CSF, as from a hemorrhage, may also give rise to fever., ${ }^{4,12}$ The usual criteria for infection are therefore confounded by the initial pathology, and the only reliable criterion is isolation of a microorganism from the ventricular CSF drawn from the EVD catheter. ${ }^{12,20}$ In some units CSF is routinely drawn after 3 or 5 days to check for the presence of bacteria, while in other units samples are drawn only when there is a clinical concern. ${ }^{6}$

In recent years, antibiotic-impregnated EVD catheters have been introduced in an attempt to reduce the risk of ventriculitis arising from catheter colonization. ${ }^{10,21-23} \mathrm{Al}-$ though these new catheters have been reported to be successful in this respect, a recent study ${ }^{18}$ raised concern that antimicrobial agents leaching from the catheters might inhibit or kill bacteria in CSF samples, thus producing falsenegative laboratory cultures and masking cases of ventriculitis, thereby interfering with or delaying treatment.

Although this is obviously a very important question, we consider that the methods used in the previous study could be improved and the question extended to cover important ancillary questions. We consider it important to extend the study to beyond the first 24 hours of perfusion, and we were also interested in determining the longer-term effect of any antibiotic wash-off on survival of bacteria in samples that were not analyzed promptly. We also wished to include 2 alternative impregnated catheters in addition to the one used in the previous study. We therefore set out to measure drug release in antibiotic-impregnated catheters to determine its effect on viability of bacteria passing through the catheters, and to determine whether it might affect bacterial viability in samples that are delayed in transit to the laboratory.

\section{Methods \\ EVD Catheters}

Ventriclear II G44130 catheters impregnated with rifampicin and minocycline were purchased from Medtronic. Bactiseal barium-filled (82-1749) and Bactiseal clear (82-1750) catheters, both impregnated with rifampicin and clindamycin, were donated by Codman and Shurtleff, Inc. The catheters will be referred to as Ventriclear, Bactiseal $\mathrm{NC}$ (for barium-filled), and Bactiseal C (for clear). Plain medical-grade silicone tubing (Dow Corning Europe) was used as a control.

\section{Test Bacterium}

The bacterium used was a strain of Staphylococcus epidermidis (F1228) isolated from a CSF shunt infection. Its identification profile by the API Staph System (bioMérieux) was 6606013, and it was susceptible to rifampicin $(0.008 \mathrm{mg} / \mathrm{L})$, clindamycin $(0.125 \mathrm{mg} / \mathrm{L})$, and minocycline $(0.125 \mathrm{mg} / \mathrm{L})$. The minimum inhibitory concentration (MIC) values were determined by Etest (bioMérieux).

\section{Catheter Perfusion System}

Catheters were mounted in hydrated conditions at $37^{\circ} \mathrm{C}$ in an established perfusion system. ${ }^{2}$ Briefly, this system consisted of a modular array of water jackets through which the catheters were inserted aseptically before the addition of sterile water. The whole modular array was encased in an outer water jacket fed by a heat circulator kept at $37^{\circ} \mathrm{C}$. The catheters were perfused with sterile physiological saline solution from a reservoir using a Watson-Marlow peristaltic pump at a rate of $20 \mathrm{ml} / \mathrm{hr}$, and perfusate drained into a second reservoir. The system was a single-pass system and did not recirculate the perfusate. All 3 types of catheters were tested at one time, each in triplicate. Samples of perfusate were aseptically collected from the catheters at intervals.

\section{Inoculation of the System}

On Days 1, 4, 10, and 21, S. epidermidis was added (to give a final concentration of $1 \times 10^{3} \mathrm{cfu} / \mathrm{ml}$ ) to the prepump perfusate reservoir so that the bacterial suspension passed through all catheters.

\section{Sampling Regimen}

Perfusate $(3.5 \mathrm{ml})$ was sampled from the catheters immediately after introduction of $S$. epidermidis to the system on each of the 4 inoculation days. Each sample was assayed quantitatively for bacterial viability by spreading $200 \mu \mathrm{l}$ immediately onto each of 3 blood agar culture plates. The samples were then divided and 1 held at $4^{\circ} \mathrm{C}$ and the other at $18^{\circ} \mathrm{C}$ to simulate delay in delivery to the laboratory. Each of these samples was plated as described after 30 minutes and after 1, 2, 4, and 18 hours of storage for bacterial survival. All bacteria surviving after passage through the catheters were tested for emergence of resistance to the 3 drugs.

\section{Drug Concentration Assays}

The concentration of rifampicin and minocycline for each daily sample was assayed by reverse phase-high performance liquid chromatography (HPLC, with an Eclipse XDB-C8 column: Agilent Technologies) and liquid chromatography-mass spectrometry (LC-MS). Column temperature was $40^{\circ} \mathrm{C}$, the volume of injection was $100 \mu \mathrm{l}$, and the flow rate was $1.0 \mathrm{ml} / \mathrm{min}$. Chromatograms were recorded at $333 \mathrm{~nm}$ (rifampicin) and $350 \mathrm{~nm}$ (minocycline).

A fast (5-minute cycle), sensitive LC-MS method for clindamycin was developed (4000 Qtrap, AB Sciex, with a Shimadzu VP HPLC). A single channel was used for the multiple-reaction monitoring assay, with parent and product ion pair (m/z) $426.00>126.10$ in positive ion electrospray mode. The declustering potential was $35 \mathrm{~V}$ and the collision energy was $23 \mathrm{~V}$. The desolvation temperature was $500^{\circ} \mathrm{C}$, and the curtain, desolvation, and nebulizer gases were set to 20,30, and 10 units, respectively. An Agilent ZORBAX SB-C18 column was used (column dimensions $2.1 \times 50 \mathrm{~mm}, 1.8 \mu \mathrm{m})$ at $50^{\circ} \mathrm{C}$ with a ballistic gradient; the mobile phase consisted of $80 \%$ water to $100 \%$ methanol (both modified with $0.01 \%$ trifluoroacetic acid).

\section{Results}

\section{Bacterial Viability on Passage Through the Catheters}

Perfusates obtained on Day 1 and assayed immediately 
(0 minute, Tables 1 and 2) all showed a reduction in the number of viable bacteria passing through the catheters compared with controls. This reduction was greatest for the two Bactiseal catheters, with the clear silicone version (Bactiseal C) providing the largest reduction. Perfusates obtained on subsequent days $(4,10$, and 21$)$ and assayed immediately showed insignificant reductions (approximately 2\%-3\%) for the 2 Bactiseal catheters but a $13 \%$ reduction for the Ventriclear catheter.

\section{Storage of Perfusates at $18^{\circ} \mathrm{C}$}

When perfusates were stored at $18^{\circ} \mathrm{C}$ (Table 1), those from the control catheters showed little reduction in bacterial viability for 4 hours, but at 18 hours there was an approximately $90 \%$ reduction. For Bactiseal C, on Day 1 of sampling there was a considerable decrease in viable bacteria to $12.2 \%$ of the control value, which was sustained when samples were stored for up to 4 hours. There was a less dramatic decrease in viability in Day 1 samples for Bactiseal NC (to $45 \%$ of control value), and this had decreased to $20.4 \%$ after storage for 4 hours. The decrease in bacterial viability for Day 1 samples from Ventriclear was far smaller (to $73.5 \%$ of control value), and this fell to $37.8 \%$ after storage for 4 hours. In later samples, loss of viability was not significant in either type of Bactiseal catheter (to 98\%-99\%) and the loss on storage for 4 hours

TABLE 1. Percentage viability of bacteria after passing through the catheters when samples were then stored at $18^{\circ} \mathrm{C}$ for up to 18 hours* $^{*}$

\begin{tabular}{|c|c|c|c|c|c|c|c|}
\hline \multirow[b]{2}{*}{ Catheter } & \multirow{2}{*}{$\begin{array}{c}\text { Day of } \\
\text { Sampling }\end{array}$} & \multicolumn{6}{|c|}{ Time of Storage (hrs) } \\
\hline & & 0 & 0.5 & 1 & 2 & 4 & 18 \\
\hline \multicolumn{8}{|l|}{ Control } \\
\hline & 1 & 100 & 98.6 & 96.5 & 95.5 & 94 & 10.2 \\
\hline & 4 & 100 & 99.4 & 96.7 & 96.5 & 95.9 & 9.6 \\
\hline & 10 & 100 & 99.4 & 97.6 & 96.5 & 95.9 & 10.2 \\
\hline & 21 & 100 & 97.9 & 97.7 & 96.7 & 95.7 & 9.5 \\
\hline \multicolumn{8}{|l|}{ Bactiseal C } \\
\hline & 1 & 12.2 & 12.2 & 12.2 & 12.2 & 12.2 & 0 \\
\hline & 4 & 98.2 & 96.9 & 96.7 & 96.5 & 96.5 & 9.3 \\
\hline & 10 & 98.2 & 98.2 & 98 & 95.5 & 92.9 & 9.3 \\
\hline & 21 & 97.9 & 96.1 & 95.5 & 94.3 & 91.4 & 8.9 \\
\hline \multicolumn{8}{|c|}{ Bactiseal NC } \\
\hline & 1 & 44.9 & 30.6 & 28.6 & 28.6 & 20.4 & 0 \\
\hline & 4 & 97.8 & 97.1 & 96.9 & 95.9 & 95.9 & 9.6 \\
\hline & 10 & 97.8 & 97.1 & 96.9 & 96.7 & 96.7 & 9.6 \\
\hline & 21 & 96.7 & 96.3 & 95.7 & 95.3 & 95.3 & 7.9 \\
\hline \multicolumn{8}{|l|}{ Ventriclear } \\
\hline & 1 & 73.5 & 69.4 & 69.4 & 61.2 & 37.8 & 0.6 \\
\hline & 4 & 87.1 & 87.1 & 87.3 & 86.1 & 85.3 & 8 \\
\hline & 10 & 87.1 & 87.1 & 87.3 & 86.1 & 88.4 & 8 \\
\hline & 21 & 87 & 87 & 86.2 & 87.8 & 85 & 7.9 \\
\hline
\end{tabular}

${ }^{*}$ For all antimicrobial EVDs there was a significant reduction in bacterial viability in the perfusate obtained immediately after beginning perfusion (Day 1). Thereafter, the difference in bacterial viability between Bactiseal $C$ and Bactiseal NC was not significantly different from control catheters $(p>0.05)$, but the difference was significant for Ventriclear catheters $(p<0.05)$.
TABLE 2. Percentage viability of bacteria after passing through the catheters when samples were then stored at $4^{\circ} \mathrm{C}$ for up to 18 hours*

\begin{tabular}{|c|c|c|c|c|c|c|c|}
\hline \multirow[b]{2}{*}{ Catheter } & \multirow{2}{*}{$\begin{array}{c}\text { Day of } \\
\text { Sampling }\end{array}$} & \multicolumn{6}{|c|}{ Time of Storage (hrs) } \\
\hline & & 0 & 0.5 & 1 & 2 & 4 & 18 \\
\hline \multicolumn{8}{|l|}{ Control } \\
\hline & 1 & 100 & 99.6 & 97.6 & 96.1 & 94.9 & 32.7 \\
\hline & 4 & 100 & 98.6 & 96.5 & 95.5 & 93.9 & 37.8 \\
\hline & 10 & 100 & 99.6 & 98.0 & 98.2 & 95.9 & 34.7 \\
\hline & 21 & 100 & 97.7 & 97.7 & 97.7 & 97.7 & 33.2 \\
\hline \multicolumn{8}{|l|}{ Bactiseal C } \\
\hline & 1 & 12.2 & 12.2 & 12.2 & 12.2 & 12.2 & 6.5 \\
\hline & 4 & 99.2 & 98.4 & 97.3 & 97.1 & 97.1 & 31.7 \\
\hline & 10 & 98.2 & 98.4 & 97.1 & 97.3 & 97.1 & 32.7 \\
\hline & 21 & 96.9 & 97.1 & 95.9 & 96.1 & 95.9 & 32.2 \\
\hline \multicolumn{8}{|c|}{ Bactiseal NC } \\
\hline & 1 & 44.9 & 28.6 & 28.6 & 28.6 & 24.5 & 8.2 \\
\hline & 4 & 97.8 & 97.8 & 97.8 & 97.8 & 96.7 & 34.7 \\
\hline & 10 & 97.8 & 96.9 & 96.5 & 95.9 & 95.1 & 34.7 \\
\hline & 21 & 96.5 & 96.5 & 96.5 & 96.5 & 95.5 & 33.2 \\
\hline \multicolumn{8}{|l|}{ Ventriclear } \\
\hline & 1 & 73.5 & 67.3 & 61.2 & 59.2 & 37.8 & 8.8 \\
\hline & 4 & 87.8 & 87.8 & 87.8 & 85.7 & 85.3 & 29.6 \\
\hline & 10 & 89.0 & 89.0 & 89.0 & 89.0 & 88.4 & 31.5 \\
\hline & 21 & 87.6 & 88.6 & 88.6 & 87.8 & 87.2 & 29.2 \\
\hline
\end{tabular}

* For all antimicrobial EVDs there was a significant reduction in bacterial viability in the perfusate obtained immediately after beginning perfusion on Day 1. Upon storage for 4 hours, viability was not further reduced for Bactiseal $\mathrm{C}$ but was reduced in the case of Bactiseal NC and Ventriclear.

was not significant, but for later samples from the Ventriclear catheters there was a decrease in bacterial viability to $87.1 \%$ of controls and a slightly further decrease to $85 \%$ after storage for 4 hours.

Bacterial viability after storage at this temperature for 18 hours was low in all catheters and similar to control values for that storage period. The difference in viable bacteria count for the two Bactiseal catheters from the controls for samples after Day 1 was not statistically significant, but it was significant for controls compared with the Ventriclear catheter $(\mathrm{p}=0.046)$.

\section{Storage of Perfusates at $4^{\circ} \mathrm{C}$}

When stored at $4^{\circ} \mathrm{C}$ (Table 2), the perfusates from control catheters showed less reduction in bacterial viability after 18 hours than those stored at the higher temperature, but it was still $>60 \%$. For the 3 antibiotic-impregnated catheters, the loss in viability was similar to that found at $18^{\circ} \mathrm{C}$.

\section{Assays of Drug Concentrations in Perfusates}

Mean concentrations of rifampicin from Bactiseal C, Bactiseal NC, and Ventriclear catheters for perfusates collected immediately (time $=0$ ) on Day 1 were $3.25 \mathrm{mg} / \mathrm{L}$, $0.39 \mathrm{mg} / \mathrm{L}$, and $0.31 \mathrm{mg} / \mathrm{L}$, respectively. Mean concentrations of clindamycin in these samples for Bactiseal $\mathrm{C}$ were 
significantly higher $(24.58 \mathrm{mg} / \mathrm{L})$ than for Bactiseal NC $(6.05 \mathrm{mg} / \mathrm{L} ; \mathrm{p}=0.017)$. The mean concentration of minocycline at this time point for Ventriclear was $2.57 \mathrm{mg} / \mathrm{L}$. However, the concentrations of all drugs in all 3 types of catheters fell sharply in the following few hours, and by Day 1 or 2 they had reached low plateau levels (Figs. 1-3). All assays were performed in triplicate with samples from triplicate catheters of each type.

\section{Discussion}

Because of the reliance on positive CSF cultures for the diagnosis of EVD ventriculitis, the possibility that antimicrobial catheters might interfere with this by inhibiting bacterial growth is a serious question. Stevens et al..$^{18}$ set out to address this issue, but their paper can be criticized on several methodological points. They used a static method to fill the EVD catheters with saline and left this in the catheters for various lengths of time without any flow. This would give different results from those used in our paper, which we consider to be more relevant to EVD catheter conditions in use. Their study covered only the first 24 hours, but samples of CSF for diagnosis are unlikely to be obtained so early after placement of the catheter, and practice varies: some obtain samples at 3 or 5 days, some 3 times weekly, and some only if clinically indicated, ${ }^{5-7,14}$ and clinical concern regarding infection usually does not arise so soon as within 24 hours after placement. . $^{8,9,15}$ The detection method of Stevens et al. for drug release (capillary electrophoresis) did not allow quantitative determination of actual drug levels in the saline, whereas our methods (HPLC and LC-MS) were able to accurately determine the concentrations of drugs in the perfusates at each time point. It could also be said that their assay for antimicrobial activity, performed by dropping $30 \mu \mathrm{l}$ of sample onto the surfaces of seeded agar plates and measuring the zones after incubation, would lead to variation in zone sizes due to inconsistent spread of the droplets. Finally, they tested only 1 of the antimicrobial catheter types that is commercially available, whereas we tested all 3 , with the exception of silver-processed catheters that would not be expected to elute antimicrobial activity. ${ }^{16}$ In the clinic, CSF samples should be transmitted to the laboratory immediately for prompt examination, ${ }^{13}$ but in reality they are sometimes delayed for some hours and occasionally until the following day (especially on weekends), and they might be placed in a refrigerator until sent. This is why we examined the effect of antimicrobials on bacterial viability after storage.

Our results showed that for each of the 3 catheters, enough antimicrobial agent was released to affect the viability of bacteria passing through the catheter on the first day and especially in the first few hours. In this respect, our results confirm those of Stevens et al. ${ }^{18}$ However, after this time there was a significant decline in drug concentrations to low levels in all catheters. There were important differences in results between the catheters tested. The amount of rifampicin released from all 3 catheter types over the test period of 21 days was broadly similar, but the Bactiseal $\mathrm{C}$ catheters released approximately 10 times as much as the Bactiseal NC and Ventriclear catheters

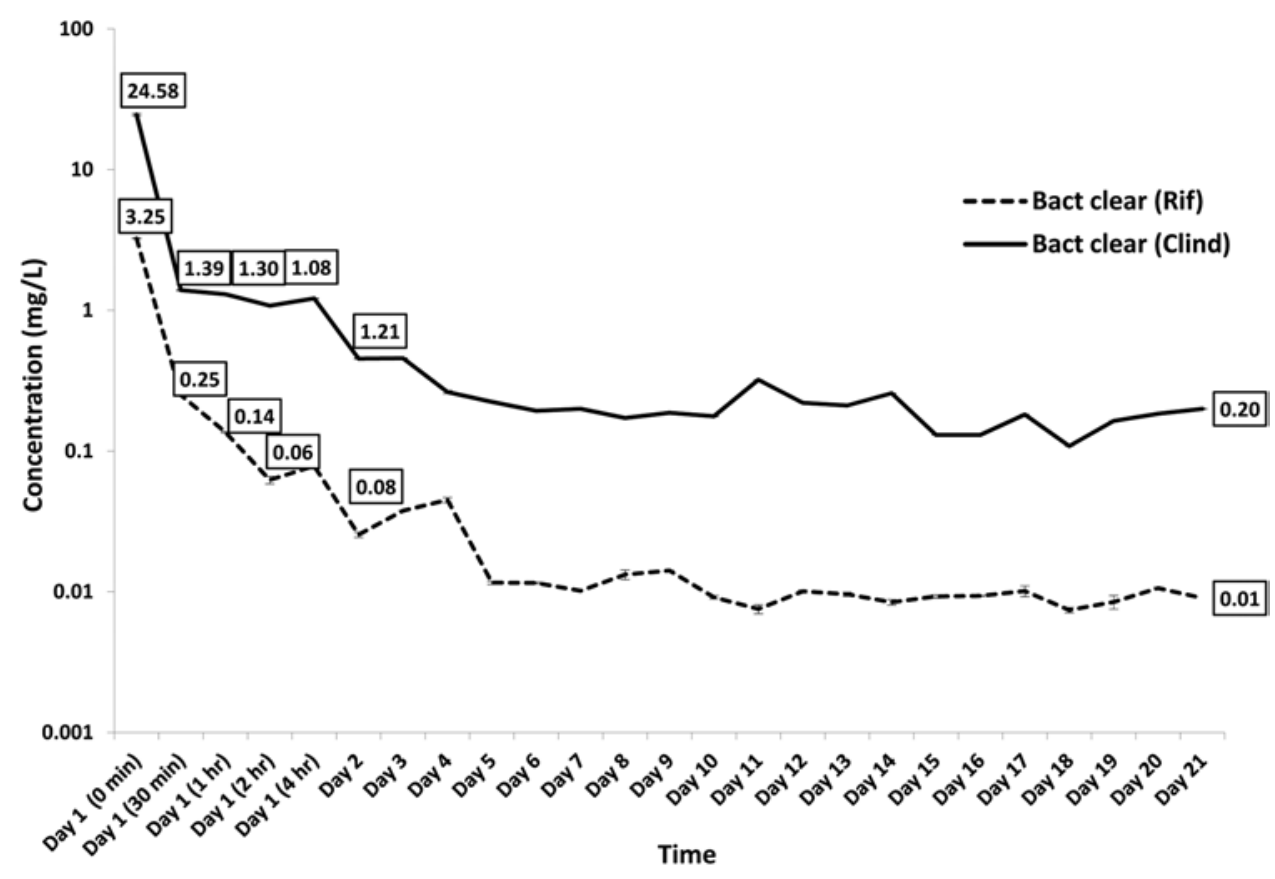

FIG. 1. Antimicrobial activity of samples taken daily from Bactiseal C (Bact clear) catheters for 21 days. On Day 1, the concentration of rifampicin (Rif) released immediately after beginning perfusion was $3.25 \mathrm{mg} / \mathrm{L}$, and the concentration then dropped significantly $(0.25 \mathrm{mg} / \mathrm{L}$ at 30 minutes, $0.14 \mathrm{mg} / \mathrm{L}$ at 1 hour, $0.06 \mathrm{mg} / \mathrm{L}$ at 2 hours, and $0.08 \mathrm{mg} / \mathrm{L}$ at 4 hours). Thereafter (Days 2-21) the rifampicin concentration plateaued and was $0.01 \mathrm{mg} / \mathrm{L}$ on Day 21 . On Day 1 , the concentration of clindamycin (Clind) released immediately was $24.58 \mathrm{mg} / \mathrm{L}$, and the concentration then dropped significantly $(1.39 \mathrm{mg} / \mathrm{L}$ at 30 minutes, $1.30 \mathrm{mg} / \mathrm{L}$ at 1 hour, 1.08 $\mathrm{mg} / \mathrm{L}$ at 2 hours, and $1.21 \mathrm{mg} / \mathrm{L}$ at 4 hours). The concentration of clindamycin for samples taken on Days 2-21 plateaued and was $0.20 \mathrm{mg} / \mathrm{L}$ on Day 21. 


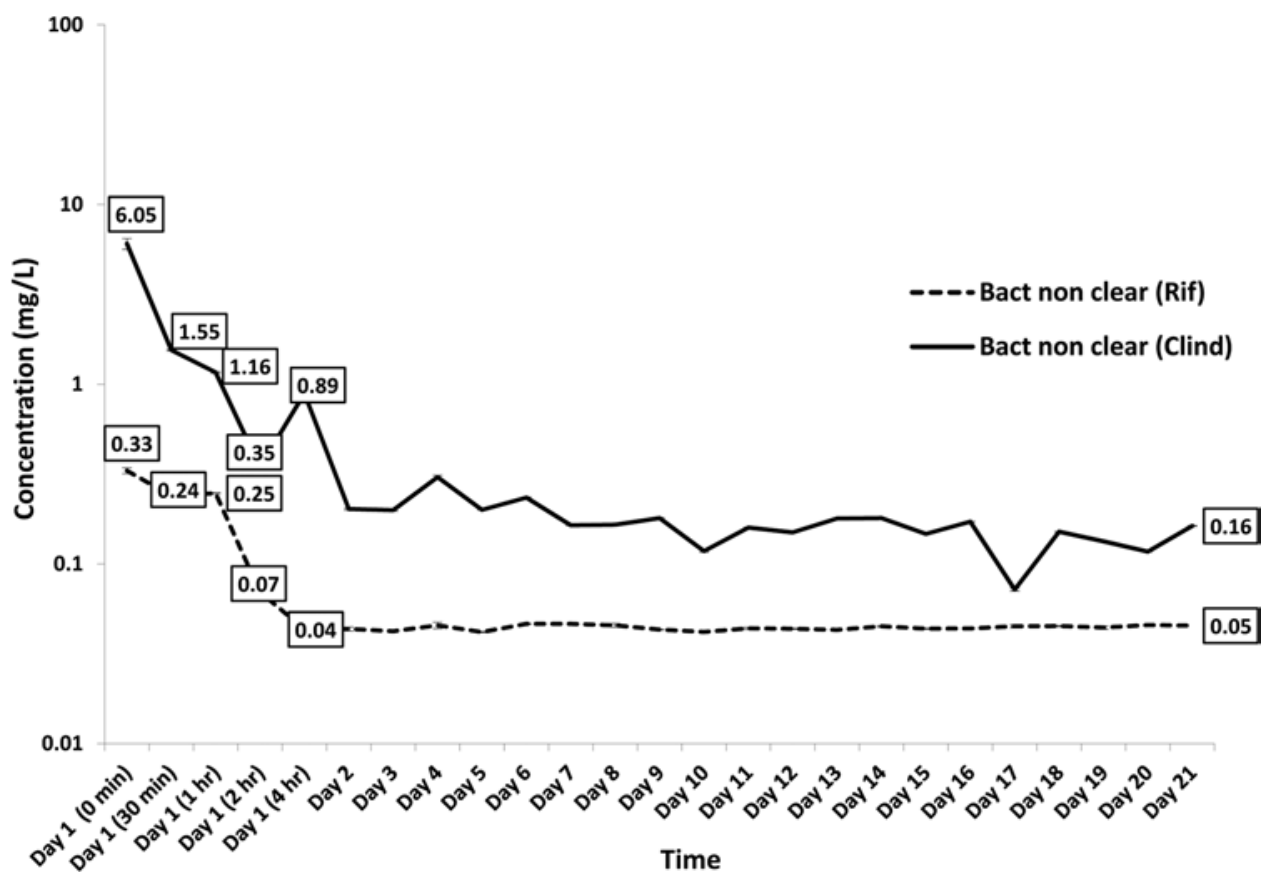

FIG. 2. Antimicrobial activity of samples taken daily from Bactiseal NC (Bact non clear) catheters for 21 days. On Day 1, the concentration of rifampicin (Rif) released immediately after beginning perfusion was $0.33 \mathrm{mg} / \mathrm{L}$, and the concentration then dropped significantly $(0.24 \mathrm{mg} / \mathrm{L}$ at 30 minutes, $0.25 \mathrm{mg} / \mathrm{L}$ at 1 hour, $0.07 \mathrm{mg} / \mathrm{L}$ at 2 hours, and $0.04 \mathrm{mg} / \mathrm{L}$ at 4 hours). Thereafter (Days 2-21) the rifampicin concentration plateaued and was $0.05 \mathrm{mg} / \mathrm{L}$ on Day 21. On Day 1, the concentration of clindamycin (Clind) released immediately was $6.05 \mathrm{mg} / \mathrm{L}$, and the concentration then dropped significantly $(1.55 \mathrm{mg} / \mathrm{L}$ at 30 minutes, $1.16 \mathrm{mg} / \mathrm{L}$ at 1 hour, $0.89 \mathrm{mg} / \mathrm{L}$ at 2 hours, and $0.20 \mathrm{mg} / \mathrm{L}$ at 4 hours). The concentration of clindamycin for samples taken on Days 2-21 plateaued and was $0.16 \mathrm{mg} / \mathrm{L}$ on Day 21.

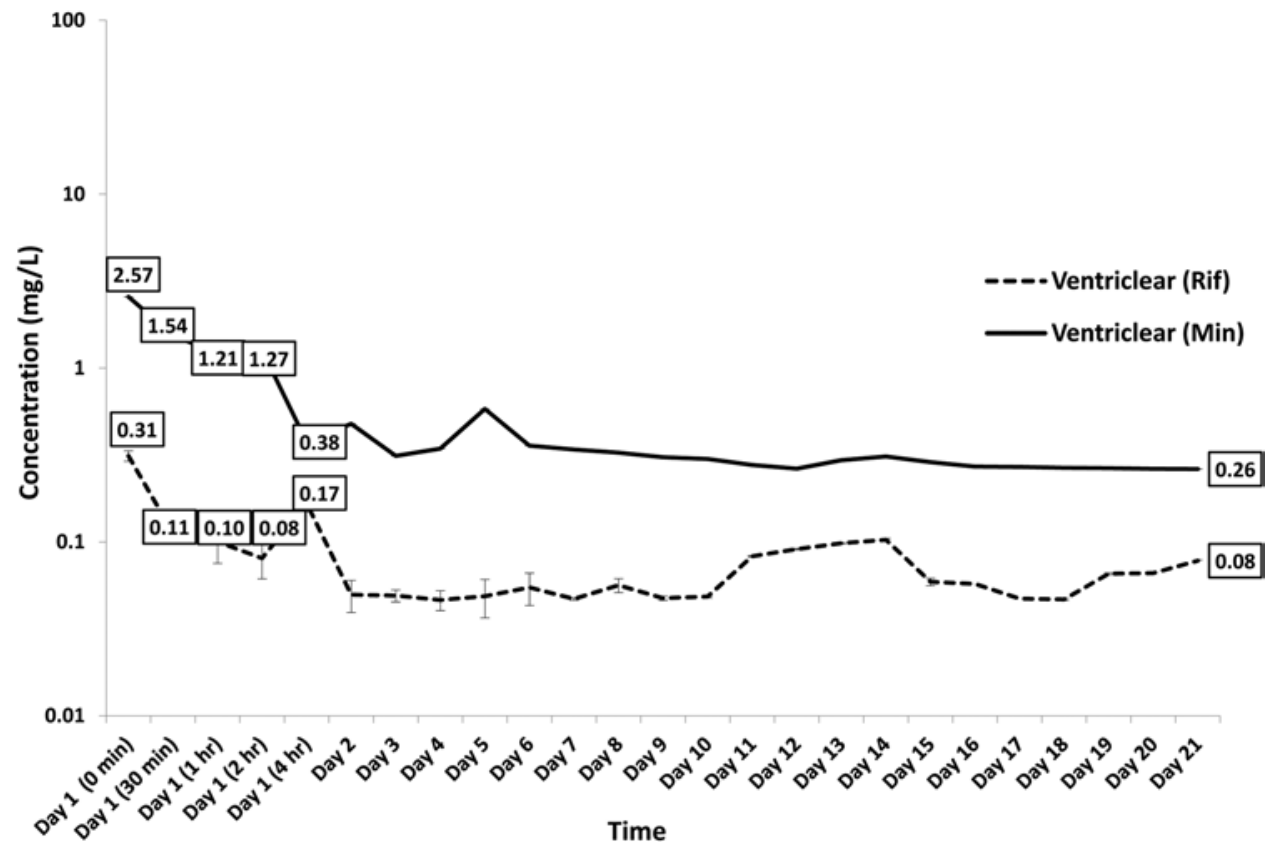

FIG. 3. Antimicrobial activity of samples taken daily from Ventriclear catheters for 21 days. On Day 1 , the concentration of rifampicin (Rif) released immediately was $0.31 \mathrm{mg} / \mathrm{L}$, and the concentration then dropped $(0.11 \mathrm{mg} / \mathrm{L}$ at 30 minutes, $0.10 \mathrm{mg} / \mathrm{L}$ at 1 hour, $0.08 \mathrm{mg} / \mathrm{L}$ at 2 hours, and $0.17 \mathrm{mg} / \mathrm{L}$ at 4 hours). Thereafter (Days 2-21), the rifampicin concentration plateaued and was $0.08 \mathrm{mg} / \mathrm{L}$ on Day 21. On Day 1, the concentration of minocyline (Min) released immediately was $2.57 \mathrm{mg} / \mathrm{L}$, and the concentration then dropped (1.54 mg/L at 30 minutes, $1.21 \mathrm{mg} / \mathrm{L}$ at 1 hour, $1.27 \mathrm{mg} / \mathrm{L}$ at 2 hours, and $0.38 \mathrm{mg} / \mathrm{L}$ at 4 hours). The concentration of minocyline for samples taken daily thereafter (Days 2-21) plateaued and was $0.26 \mathrm{mg} / \mathrm{L}$ on Day 21. 
within the first hour. Again, the amount of clindamycin released in this period was significantly higher from the Bactiseal $\mathrm{C}$ catheters than from the Bactiseal NC catheters. The drug concentrations in the catheters were identical (rifampicin $0.25-0.7 \mathrm{mg} / \mathrm{g}$ and clindamycin $0.85-1.54$ $\mathrm{mg} / \mathrm{g}$; manufacturer's data sheet), and the dimensions of the catheters were also identical. We know of no evidence that the inclusion of barium sulfate as a filler in the Bactiseal NC catheters would affect drug release to this extent. The difference in drug release is reflected in the bacterial viability results for perfusate sampled during this early period, in which the reduction in viable count was significantly greater for Bactiseal $\mathrm{C}$ than for Bactiseal NC (and both reduced the viable count more than the Ventriclear catheter in this period). However, after this period and by Day 4, the effect on viable count of both Bactiseal catheters was negligible, whereas there was a persistent reduction in viable count for the Ventriclear catheter for the entire 21-day period. Referring to the MICs of the 3 drugs, the test bacterium was inhibited by $0.008 \mathrm{mg} / \mathrm{L}$ of rifampicin, $0.125 \mathrm{mg} / \mathrm{L}$ of clindamycin, and $0.125 \mathrm{mg} / \mathrm{L}$ of minocycline, and the measured drug levels exceeded these throughout. However, after the initial burst period the MICs were not greatly exceeded, and the conditions in which they were determined (solid medium, Etest) were very different from their exposure in fluid medium. Also, the Etest determines inhibitory activity, not lethal activity, which is likely to account for the survival of susceptible bacteria in the perfusates. The effects of storage at different temperatures showed no difference between temperatures, but there were differences between catheters at both storage temperatures. For the first 4 hours there was negligible reduction in bacterial viability for both Bactiseal catheters for Day 4 samples onward, whereas there was a persistent $13 \%-15 \%$ reduction in the case of Ventriclear. For all samples stored for 18 hours at both temperatures, including those from plain control catheters, there was a significant reduction in viable count. This could have been influenced by the perfusion medium, physiological saline, which lacks the glucose and protein content of CSF.

While our findings confirm those of Stevens et al. for the first few hours of drainage, we have shown that for the subsequent 21 days there is a negligible effect on bacterial viability, both passing through the catheters and in storage, for the Bactiseal catheters. While the effect appears greater for Ventriclear catheters, it is doubtful whether this is clinically important.

\section{Conclusions}

Assays of drugs released from antimicrobial catheters showed inhibitory levels only on Day 1 of perfusion; thereafter they declined to subinhibitory levels. The effect on viability of $S$. epidermidis passing through the catheters was different for each type of catheter, but overall, loss of viability was not significant after Day 1 . These results were reflected in storage of samples to simulate delay in transit to the laboratory. It is very unlikely that the high drug levels found in the first few hours by us and reported by Stevens et al. are clinically relevant, as CSF samples are not usually obtained for diagnosis or monitoring for infection during this period. It would therefore appear that use of none of the 3 catheters is likely to interfere with diagnostic CSF culture.

\section{Acknowledgment}

We are grateful to Mr. Brian Richards, who devised the assay protocol.

\section{References}

1. Babu MA, Patel R, Marsh WR, Wijdicks EF: Strategies to decrease the risk of ventricular catheter infections: a review of the evidence. Neurocrit Care 16:194-202, 2012

2. Bayston R, Fisher LE, Weber K: An antimicrobial modified silicone peritoneal catheter with activity against both Grampositive and Gram-negative bacteria. Biomaterials 30:31673173, 2009

3. Beer R, Lackner P, Pfausler B, Schmutzhard E: Nosocomial ventriculitis and meningitis in neurocritical care patients. J Neurol 255:1617-1624, 2008

4. Fernandez A, Schmidt JM, Claassen J, Pavlicova M, Huddleston D, Kreiter KT, et al: Fever after subarachnoid hemorrhage: risk factors and impact on outcome. Neurology 68:1013-1019, 2007

5. Flint AC, Rao VA, Renda NC, Faigeles BS, Lasman TE, Sheridan W: A simple protocol to prevent external ventricular drain infections. Neurosurgery 72:993-999, 2013

6. Hader WJ, Steinbok P: The value of routine cultures of the cerebrospinal fluid in patients with external ventricular drains. Neurosurgery 46:1149-1155, 2000

7. Hoefnagel D, Dammers R, Ter Laak-Poort MP, Avezaat CJ: Risk factors for infections related to external ventricular drainage. Acta Neurochir (Wien) 150:209-214, 2008

8. Holloway KL, Barnes T, Choi S, Bullock R, Marshall LF, Eisenberg HM, et al: Ventriculostomy infections: the effect of monitoring duration and catheter exchange in 584 patients. J Neurosurg 85:419-424, 1996

9. Kanter RK, Weiner LB, Patti AM, Robson LK: Infectious complications and duration of intracranial pressure monitoring. Crit Care Med 13:837-839, 1985

10. Kubilay Z, Amini S, Fauerbach LL, Archibald L, Friedman WA, Layon AJ: Decreasing ventricular infections through the use of a ventriculostomy placement bundle: experience at a single institution. J Neurosurg 118:514-520, 2013

11. Leverstein-van Hall MA, Hopmans TEM, van der Sprenkel JW, Blok HEM, van der Mark WAMA, Hanlo PW, et al: A bundle approach to reduce the incidence of external ventricular and lumbar drain-related infections. J Neurosurg 112:345-353, 2010

12. Lozier AP, Sciacca RR, Romagnoli MF, Connolly ES Jr: Ventriculostomy-related infections: a critical review of the literature. Neurosurgery 51:170-182, 2002

13. Rajesh NT, Dutta S, Prasad R, Narang A: Effect of delay in analysis on neonatal cerebrospinal fluid parameters. Arch Dis Child Fetal Neonatal Ed 95:F25-F29, 2010

14. Schade RP, Schinkel J, Roelandse FW, Geskus RB, Visser LG, van Dijk JMC, et al: Lack of value of routine analysis of cerebrospinal fluid for prediction and diagnosis of external drainage-related bacterial meningitis. J Neurosurg 104:101108,2006

15. Schultz M, Moore K, Foote AW: Bacterial ventriculitis and duration of ventriculostomy catheter insertion. J Neurosci Nurs 25:158-164, 1993

16. Secer HI, Kural C, Kaplan M, Kilic A, Duz B, Gonul E, et al: Comparison of the efficacies of antibiotic-impregnated and silver-impregnated ventricular catheters on the prevention of infections. An in vitro laboratory study. Pediatr Neurosurg 44:444-447, 2008

17. Sonabend AM, Korenfeld Y, Crisman C, Badjatia N, Mayer 
SA, Connolly ES Jr: Prevention of ventriculostomy-related infections with prophylactic antibiotics and antibiotic-coated external ventricular drains: a systematic review. Neurosurgery 68:996-1005, 2011

18. Stevens EA, Palavecino E, Sherertz RJ, Shihabi Z, Couture DE: Effects of antibiotic-impregnated external ventricular drains on bacterial culture results: an in vitro analysis. J Neurosurg 113:86-92, 2010

19. Stoodley P, Braxton EE Jr, Nistico L, Hall-Stoodley L, Johnson S, Quigley M, et al: Direct demonstration of Staphylococcus biofilm in an external ventricular drain in a patient with a history of recurrent ventriculoperitoneal shunt failure. Pediatr Neurosurg 46:127-132, 2010

20. Sundbärg G, Nordström CH, Söderström S: Complications due to prolonged ventricular fluid pressure recording. Br J Neurosurg 2:485-495, 1988

21. Tamburrini G, Massimi L, Caldarelli M, Di Rocco C: Antibiotic impregnated external ventricular drainage and third ventriculostomy in the management of hydrocephalus associated with posterior cranial fossa tumours. Acta Neurochir (Wien) 150:1049-1056, 2008

22. Wong GKC, Ip M, Poon WS, Mak CWK, Ng RYT: Antibiotics-impregnated ventricular catheter versus systemic antibiotics for prevention of nosocomial CSF and non-CSF infections: a prospective randomised clinical trial. J Neurol Neurosurg Psychiatry 81:1064-1067, 2010

23. Zabramski JM, Whiting D, Darouiche RO, Horner TG, Olson J, Robertson C, et al: Efficacy of antimicrobial-impregnated external ventricular drain catheters: a prospective, randomized, controlled trial. J Neurosurg 98:725-730, 2003

\section{Author Contributions}

Conception and design: Bayston. Acquisition of data: Ashraf, Ortori. Analysis and interpretation of data: all authors. Drafting the article: Bayston, Ortori. Critically revising the article: Bayston, Ortori. Reviewed submitted version of manuscript: Ashraf, Ortori. Approved the final version of the manuscript on behalf of all authors: Bayston. Administrative/technical/material support: Ashraf. Study supervision: Bayston.

\section{Supplemental Information}

Previous Presentation

Part of this work was presented orally at the 56th Annual Meeting of the Society for Research into Hydrocephalus and Spina Bifida in York, United Kingdom, in 2012, and an abstract appeared in the program.

\section{Correspondence}

Roger Bayston, Biomaterials-Related Infection Group, School of Medicine, University of Nottingham, Queens Medical Centre, C Floor West Block, Nottingham NG7 2UH, United Kingdom. email: roger.bayston@nottingham.ac.uk. 